Library, N. W. Bldg.

AUG 191952

\title{
Fire Tests of Gunite Slabs and Partitions
}

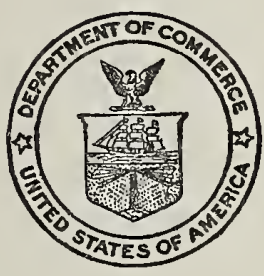

United States Department of Commerce

National Bureau of Standards

Building Materials and Structures Report 131 


\section{BUILDING MATERIALS AND STRUCTURES REPORTS}

On request, the Superintendent of Documents, U. S. Government Printing Office, Washington $25, \mathrm{D}$. C., will place your name on a special mailing list to receive notices of new reports in this series as soon as they are issued. There will be no charge for receiving such notices.

An alternative method is to deposit with the Superintendent of Documents the sum of $\$ 5$, with the request that the reports be sent to you as soon as issued, and that the cost thereof be charged against your deposit. This will provide for the mailing of the publications without delay. You will be notified when the amount of your deposit has become exhausted.

If 100 copies or more of any report are ordered at one time, a discount of 25 percent is allowed. Send all orders and remittances to the Superintendent of Documents, U. S. Government Printing Office, Washington $25, D$. C.

The following publications in this series are available by purchase from the Superintendent of Documents at the prices indicated:

BMS2

BMS3

BMS4

- BMS5

BMS6

BMS8

BMS9

BMS10

BMS11

BMS12

BMS14

BMS15

BMS16

BMS17

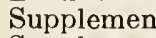

Supplem
BMS18

BMS20

BMS21

BMS22

BMS23

BMS24

BMS25

BMS26

BMS27

BMS28

BMS29

BMS30

BMS32

BMS33
Methods of Determining the Structural Properties of Low-Cost House Constructions -

Suitability of Fiber Insulating Lath as a Plaster Base-_elerated Aging of Fiber Building Boards

Structural Properties of Six Masonry Wall Constructions

Survey of Roofing Materials in the Southeastern States.

Methods of Investigation of Surface Treatment for Corrosion Protection of Steel-1 structions for Walls, Partitions, Floors, and Roofs

Structural Properties of One of the "Keystone Beam Steel Floor" Constructions Sponsored by the H. H. Robertson Co

Structural Properties of the Curren Fabrihome Corporation's "Fabrihome" Constructions for Walls and Partitions

Structural Properties of "Steelox" Constructions for Walls, Partitions, Floors, and Roofs Sponsored by Steel Buildings, Inc _._._._.

Indentation and Recovery of Low-Cost Floor Coverings

Structural Properties of "Wheeling Long-Span Steel Floor" Construction Sponsored by the Wheeling Corrugating Co "Tilecret,"

Structural Properties of a "Tilecrete" Floor Construction Sponsored by Tilecrete Floors, Inc

Sound Insulation of Wall and Floor Constructions

nt to BMS17, Sound Insulation of Wall and Floor Constructions

No. 2 to BMS17, Sound Insulation of Wall and Floor Constructions_....... 15\&

Structural Properties of "Pre-fab" Constructions for Walls, Partitions, and Floors Sponsored by the Harnischfeger Corporation

Structural Properties of "Twachtman" Constructions for Walls and Floors Sponsored by Connecticut Pre-Cast Buildings Corporation

Structural Properties of a Concrete-Block Cavity-Wall Construction Sponsored by the National Concrete Masonry Association -

Structural Properties of "Dun-Ti-Stone" Wall Construction Sponsored by the W. E. Dunn Manufacturing Co Manufacturers Association of New York, Inc Structural Properties of a Reinforced-Brick Wall Construction and a Brick-Tile Cavity-Wall Construction Sponsored by the Structural Clay Products Institute Structural Properties of Conventional Wood-Frame Constructions for Walls, Partitions, Floors, and Roofs
Structural Properties of "Nelson Pre-Cast Concrete Foundation" Wall Construction
Sponsored by the Nelson Cement Stone Co., Inc Sponsored by the Nelson Cement Stone Co., Inc Bender Body Co

Backflow Prevention in Over-Rim Water Supplies

Survey of Roofing Materials in the Northeastern States
Structural Properties of a Wood-Frame Wall Construction Sponsored by the Douglas Fir Plywood Association.

Structural Properties of Two Brick-Concrete-Block Wall Constructions and a Concrete-Block Wall Construction Sponsored by the National Concrete Masonry Association Wall Construction Sponsored by the National Concrete Masonry

Plastic Calking Materials.

[List continued on cover page III] 
UNITED STATES DEPARTMENT OF COMMERCE - Charles Sawyer, Secretary

National BUREaU OF STANDARDS - A. V. Astin, Acting Director

\title{
Fire Tests of Gunite Slabs and Partitions
}

\author{
Nolan D. Mitchell
}

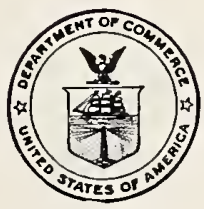

Building Materials and Structures Report 131

Issued May 12, 1952

For sale by the Superintendent of Documents, U, S. Government Printing Office, Washington 25, D. C. Price 15 cents 


\section{Foreword}

The use of noncombustible constructions for restricting the spread of fire makes necessary a knowledge of the fire-resistive properties of the materials used in them.

This paper gives the results of fire tests on gunite concrete in the form of slabs and partitions. In addition to reporting the fire-endurance limits of gunite of conventional cement and sand mix, a means of improving the fire resistance of this type of concrete by modifying the aggregate is presented. Such modification would probably be effective in other types of concrete as well.

\section{A. V. Astin, Acting Director.}

\section{CONTENTS}

Foreword

1. Introduction and seope

2. Materials

3 . Construction of slabs and partit

4. Equipment and method of testing

5. Results of tests

5.1. Slabs

5.2. Partitions

6. Summary and discussion $\ldots \ldots \ldots$ 


\title{
Fire Tests of Gunite Slabs and Partitions
}

\author{
Nolan D. Mitchell
}

\begin{abstract}
Wight slabs and four partitions made with gunite concrete on wire-fabric reinforcement were subjected to fire-endurance tests at the National Bureau of standards. The slabs were made with aggregates composed of sand and wood sawdust, the sawdust ranging from 0 to 50) percent by volume of the aggregate. The aggregate for two partitions was sant, a thircl had a minor amount of asbestos added, and that of the fourth consisted of equal volumes of sand and sawdust. Fire-endurance limits for the slabs increased almost limearly with increased percentages of sawdust incorporated into the mix. Partitions made with samcl aggregate only in the concrete or with the addition of a small amount of asbestos fiber to the concrete showed early failure by spalling and holing through. The explosive violence of the disruptions suggested the presence of entrapped water in the dense concrete. I partition made with a concrete having equal volumes of sawdust and sand as aggregates did not spall and failed by a limiting $325 \mathrm{deg} F$ rise of temperature at a single point on the unexposed side after $70 \mathrm{~min}$ of file exposure, whereas the partitions having asbestos and sand or sand only as the aggregate reached fire-endurance limits through explosive spalling in 16 to $26 \mathrm{~min}$. Subsequent to the fire-endurance test, the partition with sawdust successfully withstood the application of the hose-stream test. The effect of the sawdust is to lower the thermal conductivity of the concrete and increase its porosity, thus making easier the escape of moisture in the form of vapor.
\end{abstract}

\section{Introduction and Scope}

Fire-endurance tests were conducted at the National Bureau of Standards on eight slabs and four partitions made of gumite concrete with welded-wire fabric reinforcement. In addition to its extensive use as linings for flumes, conduits, sewers, and reservoirs, gunite has been used as fire-protective coverings on structural nembers and as readily applied coatings, such as stucco on buildings. This type of concrete has also been suggested as suitable for the construction of fireresistant curtain walls to prevent or reduce the spread of fire among flammable materials. The tests described in this report were made to investigate the properties of gunite in slabs and partitions when subjected to standard fire exposmres.

Tests on steel columns with gypsum fire-protective coverings had shown that a gypsum concrete having wood chips as the aggregate was superior in fire protection to other types of gypsum encasement tested. ${ }^{1}$ For this reason, sawdust was suggested as a substitute for part of the sand aggregate in six of the eight gunite slabs and in one of the partitions. The mix for another partition was altered by the addition of fibered asbestos.

\section{Materials}

Two slabs were made from each of four mixes. The aggregate for one pair of slabs was composed of siliceous concrete sand. For the other three pairs, sawdust was mixed with the sand in the amounts of 30,40 , and 50 percent of the rol-

1 Nolan D. Mitchell, fire tests of columns protected with gypsum, BS J Research 10,737 (1933) RP563. ume of the aggregate. 'The ratio of cement to aggregate was $1: 4$ by volume.

Potomac River sand was used in the constrnction of the partitions. The aggregate for two partitions consisted of 3 parts of building or mortar sand and one part concrete sand by volume. The other two partitions had building and concrete sands in equal quantities in the aggregate. The mix for one partition (125) was modified by the addition of $6 \mathrm{lb}$ of asbestos fiber to each bag of cement. ${ }^{2}$ Another partition (139) was made with aggregate consisting of equal rolumes of sand and sawdust.

The sawdust for partition 139 consisted principally of white pine and maple, mostly fine, but with some planer shavings of size to pass a No. $21 / 2$ screen, and weighed about $101 / 2 \mathrm{lb} / \mathrm{ft}^{3}$.

'The welded-wire fabric used for reinforcing in both the slabs and partitions was of 4 - by 4 -in. mesh made with No. 6 galvanized wire.

Oiled plywood sheets were used to support the wire fabric and served as backing panels against which to project the gunite during the construction of the slabs and partitions. The frames for the gunite slabs as well as the supporting members of the plywood backing-up forms, were of ordinary lumber.

\section{Construction of Slabs and Partitions}

The slabs and partitions were constructed by blowing the gunite mix against plywood held as a

2 S. H. Ingberg and $N$. D. Mitchell : results of these tests were summarized in NBS Report BDST1, fire tests of wood-and metalframed partitions $(19+1)$. 
backing within the construction or fire-test frames. The water was added as the mixture left the nozzle. Wire fabric was placed in these frames so as to be in the midplane of a slab or partition. The slabs, made in the shops of the Cement Gun Company of Allentown, Pa., were shipped by truck to the National Bureau of Standards with the wood frames still attached. These frames were removed after delivery. The partitions were made at the National Bureau of Standards in the movable steel test frames of the furnace in which they were to be tested.

The concrete was placed with a cement gun having a 3-bag batch capacity. One bag of cement $(94 \mathrm{lb})$ was considered as one cubic foot. The weight of one cubic foot of sand varied with the moisture content, ranging from 73 to $100 \mathrm{lb} / \mathrm{ft}^{3}$. Six of the slabs and one partition, 139, had sawdust mixed with the sand agrregate. The ratio of cement to agoregate was $1: 4$ by volume, but varied considerably in proportion by weight because of differences in the moisture content of the sand and the low density and varied amounts of sawdust. When the gunite had been deposited to the required thickness, its surface was leveled and finished with a float.

Two groups of slabs made up of one from each mix were placed for drying, the one consisting of odd-numbered slabs before the fan outlet of a highpressure-steam unit heater, the other on the floor of the laboratory building. To determine the condition of dryness, the slabs were weighed periodically. The first fire-endurance test was made after the slabs had aged for a period exceeding 4 months.

Inasmuch as dryness also affects their fire resistance, the seasoning time of the partitions was prolonged to assure normal dryness. Partitions 124 and 125 were kept moist for 4 days, a fter which they were dried 8 weeks in a heated laboratory. Partitions 138 and 139 were left in their frames and dampened for 7 and 10 days, respectively, and were subsequently aged 4 months in the heated laboratory before testing.

The slabs were $30 \mathrm{in}$. square and nominally 2.75 in. thick. The partitions were nominally $2.5 \mathrm{in}$. thick, $16 \mathrm{ft}$ long, and $10 \mathrm{ft}$ high, filling the opening of the test frames for the wall-testing furnace.

Other characteristics of the slabs and partitions are given in section 5 .

\section{Equipment and Method of Testing}

The equipment for constructing the partitions was supplied by the manufacturer of the cement gun.

The slabs and partitions were placed to form one wall of the combustion chamber of each of two gas-fired furnaces. Details of the furnace used for testing the partitions are shown in figure 1. Temperatures in the combustion chamber of this furnace were measured with nine thermocouples. A smaller furnace used in the slab tests had four thermocouples for the same purpose.

In order to control the fire exposure in conformity with the standard reference curve, furnace temperatures were determined at 5 -min intervals during the first hour of a test and at 10 -min intervals thereafter, if the test continued. This standard requires furnace temperatures of $1,000^{\circ} \mathrm{F}$ at $5 \mathrm{~min}, 1,300^{\circ} \mathrm{F}$ at $10 \mathrm{~min}, 1,550^{\circ} \mathrm{F}$ at $30 \mathrm{~min}$, $1,700^{\circ} \mathrm{F}$ at $1 \mathrm{hr}$, and $1,850^{\circ} \mathrm{F}$ at $2 \mathrm{hr}$, etc. ${ }^{3}$

Temperatnres on the unexposed surfaces of the slabs were measured at three locations, and on the partitions at nine locations. The surface thermocouples were covered with 6 - by 6 - by 0.4 -in. asbestos felt pads secured to the surface. The disposition of the thermocouples on the unexposed face of a partition can be seen in figure 2 .

The fire exposures were continued beyond the time when the first criterion of failure in the test had been observed to determine the effects of additional exposure. Failure occurred when one of the following conditions limiting fire resistance was attained: (a) Fire damage sufficient to allow the passage of flame or gas hot enough to ignite cotton waste on the unexposed surface, or (b) the transmission of heat through the partition to raise the average temperature $250 \mathrm{deg}$ F (139 deg C) on the unexposed surface or 325 $\operatorname{deg} \mathrm{F}(181 \mathrm{deg} \mathrm{C})$ at one point on the unexposed surface. The tests of the partitions were conlucted in accordance with the Standard specification for fire tests of building construction and materials, ASA No. A2-1934. The tests of the slabs, except for size, followed the same general procedure.

All but slab 2 were set within a strong strnctural frame to give restraint against expansion in the plane of the slabs. The partitions were similarly restrained. No load was applied to either the slabs or partitions during the test.

\section{Results of Tests}

\subsection{Slabs}

Before proceeding to give the results of the tests, it may be well to call attention to the lack of uniformity in the thicknesses of the slabs. At the locations where the thermocouples were placed, the thicknesses, which were intended to be 2.75 in., ranged from 2.56 to 3.06 in. The density of these slabs ranged from $134 \mathrm{lb} / \mathrm{ft}^{3}$ for slabs with sand aggregate to $92 \mathrm{lb} / \mathrm{ft}^{3}$ for those having equal volumes of sand and sawdust for the aggregate. These data on thickness as well as the average

\footnotetext{
${ }^{3}$ See Appendix A of BMS71.
} 
of the thicknesses and the principal results of the tests are given in table 1.

The relations of composition and thickness to time to failure for the eight tests of slabs are shown in figure 3 . It should be observed that the time to failure for slabs varied with the composition and the average thicknesses at the points where the surface temperatures were measured. The time to reach limiting surface temperatures in previously reported fire tests of solid partitions of both neat and sanded plasters varied, for a given composition, approximately as the $5 / 3$ power of the thickness. Assuming that the same relation applies for gunite specimens, curves

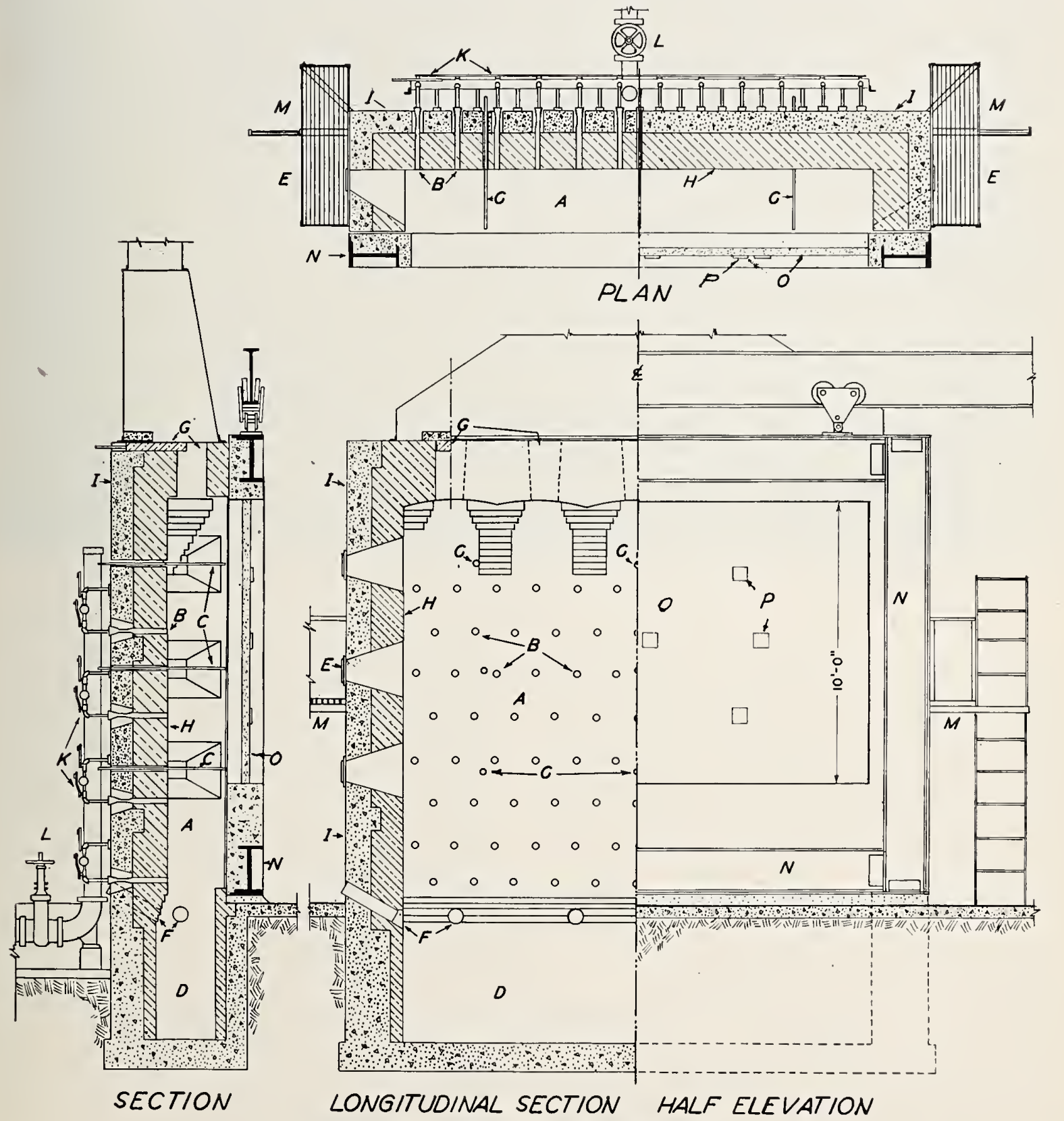

FIGURE 1. Details of wall-testing furnace.

A, Furnace chamber; B, burners; C, thermocouple protection tubes; D, pit for debris; E, observation windows; F, air inlets ; $G$, flue outlets and dampers; $H$. firebrick furnace lining; $I$, reinforced-concrete furnace shell; $K$, gas cocks: $\mathrm{L}$, control inalve $M$, ladders and platforms to observation windows; $\mathbf{N}$, movable test frante; $O$, test wall; P, felted asbestos pads covering
thermocouples. 


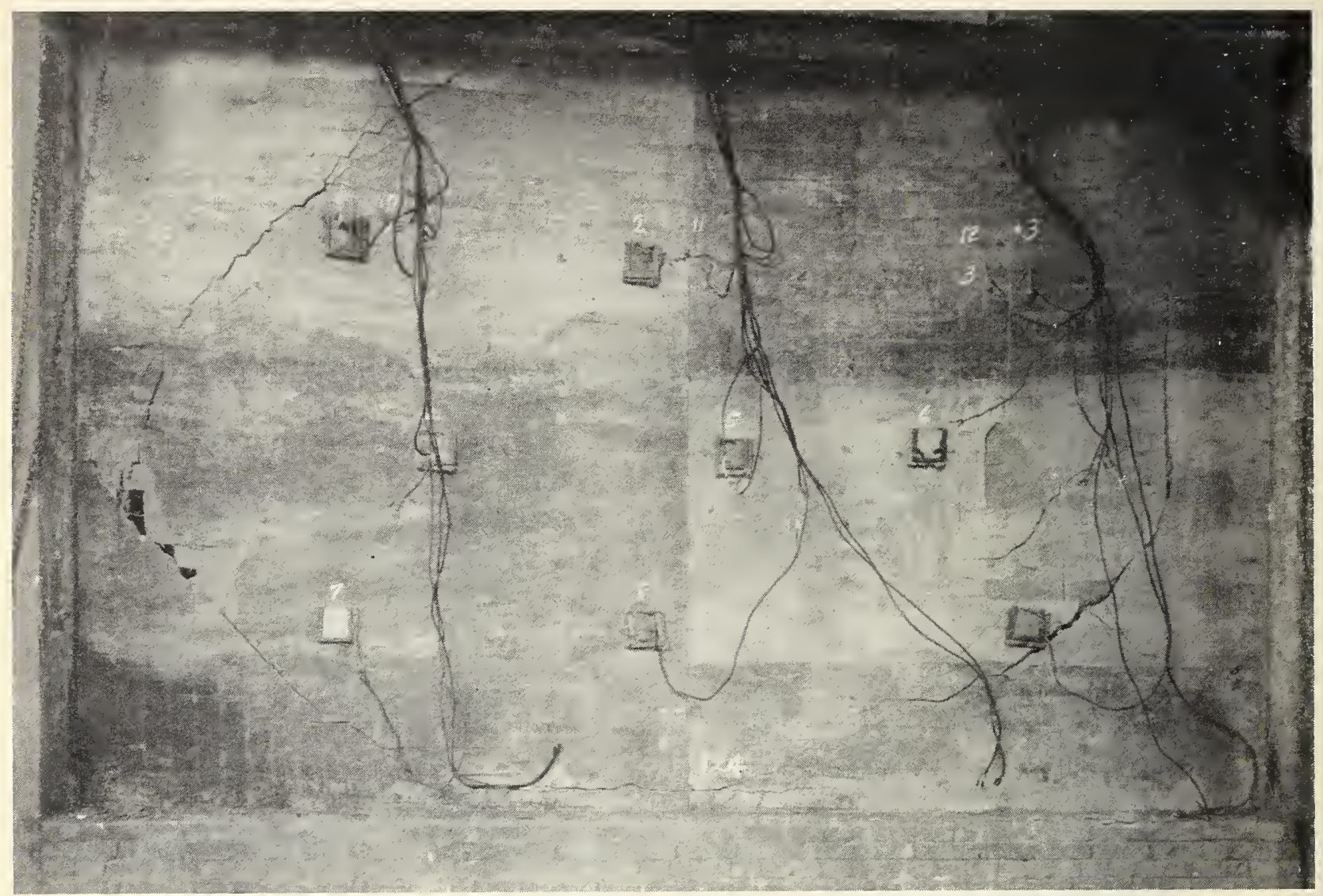

FIgURe 2. Partition 124 after 1-hr exposure of the opposite face to the fire.

showing the relation between thickness and time to failure have been drawn for each aggregate composition. These given a fair approximation of the performance to be expected from fire tests of slabs of similar compositions and of thicknesses in the range 2 to $3 \mathrm{in}$. By interpolation, dashed lines have been inserted to indicate the results to be anticipated from fire tests of slabs having, respectively, 10 and 20 percent of sawdust in the aggregates. Some of the data from the tests of partitions have also been plotted to show the relation of the results of these tests to those derived from the tests of the slabs.

Early in tests of slabs 1 and 2-the slabs with sand aggregate-steam condensed on the unexposed faces. Slab 1 showed minor cracking during the test, together with spalling of a small section at one corner, due to expansion of the slab in its frame. However, slab 2 did not crack on either face until cooling occurred, at which time

TABLE 1. Slabs made of gunite concrete.

\begin{tabular}{|c|c|c|c|c|c|c|c|c|c|c|c|c|c|}
\hline \multirow{2}{*}{ Slab } & \multicolumn{3}{|c|}{ Composition, by volume } & \multirow{2}{*}{$\begin{array}{l}\text { Average } \\
\text { thickness } \\
\text { at edges }\end{array}$} & \multicolumn{4}{|c|}{$\begin{array}{c}\text { Thickness of slabs at thermocouple } \\
\text { locations }\end{array}$} & \multicolumn{2}{|c|}{ Weight of siabs } & \multirow{2}{*}{ Exposure } & \multicolumn{2}{|c|}{$\begin{array}{l}\text { Time for limiting } \\
\text { temperature rise }\end{array}$} \\
\hline & Cement & Sawdust & Sand & & $\begin{array}{l}\text { Upper } \\
\text { north } \\
\text { quarter }\end{array}$ & $\begin{array}{l}\text { Upper } \\
\text { south } \\
\text { quarter }\end{array}$ & Center & Average & $\begin{array}{l}\text { As re- } \\
\text { ceived }\end{array}$ & $\begin{array}{c}\text { After } \\
\text { drying }\end{array}$ & & Average & $\begin{array}{l}\text { Maxi- } \\
\text { mum }\end{array}$ \\
\hline $\begin{array}{l}1 \\
2 \\
3 \\
4 \\
5 \\
6 \\
7 \\
8\end{array}$ & $\begin{array}{l}1 \\
1 \\
1 \\
1 \\
1 \\
1 \\
1 \\
1\end{array}$ & $\begin{array}{l}0 \\
0 \\
1.2 \\
1.2 \\
1.6 \\
1.6 \\
2 \\
2\end{array}$ & $\begin{array}{l}4 \\
4 \\
2.8 \\
2.8 \\
2.4 \\
2.4 \\
2 \\
2\end{array}$ & $\begin{array}{l}\text { in . } \\
2.62 \\
2.56 \\
2.5 \\
2.56 \\
2.69 \\
2.5 \\
2.56 \\
2.5\end{array}$ & $\begin{array}{l}\text { in. } \\
2.69 \\
2.62 \\
2.62 \\
2.88 \\
2.88 \\
2.62 \\
2.75 \\
2.88\end{array}$ & $\begin{array}{l}i n . \\
2.69 \\
2.75 \\
2.75 \\
2.56 \\
3.06 \\
2.62 \\
2.75 \\
2.88\end{array}$ & $\begin{array}{l}\text { in. } \\
2.88 \\
2.69 \\
2.88 \\
2.88 \\
3.0 \\
2.69 \\
2.75 \\
3.06\end{array}$ & $\begin{array}{l}\text { in. } \\
2.75 \\
2.69 \\
2.75 \\
2.77 \\
2.98 \\
2.64 \\
2.75 \\
2.94\end{array}$ & $\begin{array}{l}l b \\
203 \\
197 \\
170 \\
169 \\
168 \\
168 \\
152 \\
158\end{array}$ & $\begin{array}{l}l b \\
193 \\
189 \\
155 \\
156 \\
149 \\
142 \\
134 \\
142\end{array}$ & $\begin{array}{c}\text { Percent } \\
96 \\
102 \\
101 \\
108 \\
101 \\
99 \\
101 \\
101\end{array}$ & $\begin{array}{r}\min \\
38 \\
39 \\
71 \\
66 \\
88 \\
70 \\
85 \\
103\end{array}$ & $\begin{array}{r}\min \\
53 \\
51 \\
77 \\
75 \\
97 \\
76 \\
94 \\
107\end{array}$ \\
\hline
\end{tabular}

a Limiting rise of temperature under asbestos pads on surface; average $250 \mathrm{deg}$ F (139 deg C), maximum 325 deg $\mathrm{F}$ (181 deg C). 


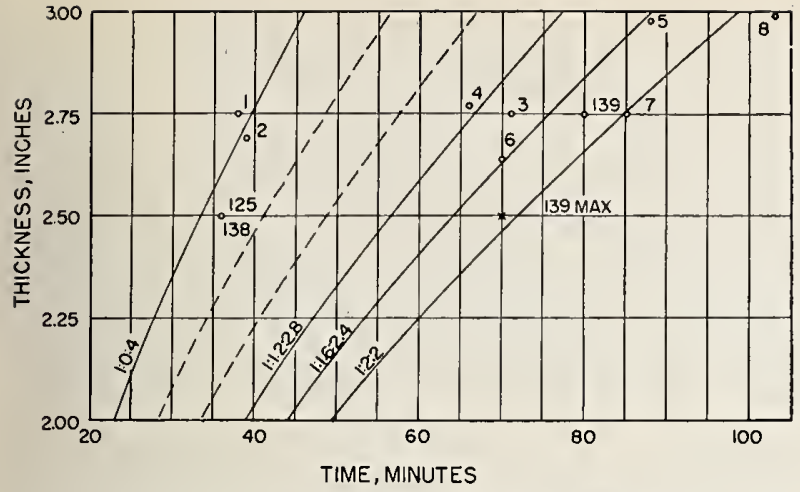

Figure 3. Effects of eomposition and thiekness of gunite on time for limiting temperatwe rise.

The first number in the proportions sbown indicates portland cement, the second sawdust, and the last sand, that is, $1: 1.2: 2.8$ equals 1 part of portland cement, 1.2 parts of sawdust, and 2.8 parts of sand, by volume.

fine edge cracks developed. Bowing of either slab amounted to less than $1 / 4$ in. The limiting average temperature rise of $250 \mathrm{deg} F$ was reached on slab 1 at $38 \mathrm{~min}$, and on slab 2 at $39 \mathrm{~min}$. 'The maximum one-point rise of $325 \mathrm{deg} \mathbf{F}$ occurred at 53 and $51 \mathrm{~min}$ on slabs 1 and 2 , respectively. The thicknesses of the slabs at the points of maximum rise were $2.88 \mathrm{in}$. on slab 1 and $2.69 \mathrm{in.}$ on slab 2.

Although steam issued from each of the six slabs made with sawdust in the aggregate, in no case was condensation observed on the surface. Upon cooling, each slab developed a few cracks.

Slabs 3 and 4, with 30 percent of sawdust in the aggregate, showed a little steam and a small quantity of smoke, more or less acrid, at the surface of the panels. Fire-endurance limits for slab thicknesses of 2.75 and $2.77 \mathrm{in}$., by a verage $250 \mathrm{deg}$ $F$ rise of temperature, occurred at 71 and $66 \mathrm{~min}$ and by maximum one-point rise of $325 \operatorname{deg} \mathrm{F}$ at 77 and $75 \mathrm{~min}$ for slabs 3 and 4 , respectively. No spalling was apparent on either slab.

In substituting 40 percent of sawdust for an equal volume of sand, slabs 5 and 6 gave results similar to those obtained with aggregate containing 30 percent of sawdust. A small quantity of steam and smoke was generated but there were no cracks. The time to the fire-endurance limits by temperature rise on the unexposed surface showed a further increase, particularly in slab 5. 'The limiting a verage temperature rise on slab 5 occurred at $88 \mathrm{~min}$ and on slab 6 at $70 \mathrm{~min}$. The respective limiting one-point temperature rises were reached at $97 \mathrm{~min}$ and $76 \mathrm{~min}$, with the respective thicknesses measured at 2.88 and $2.62 \mathrm{in}$.

Slabs 7 and 8, laving aggregate composed of equal volumes of sand and sawdust, showed greater fire resistance than that of the other slabs. Only negligible quantities of steam and smoke appeared. The limiting average temperature rises were reached at 85 and $108 \mathrm{~min}$, and the limiting maximum temperature rises at one point were ohserved at 94 and $107 \mathrm{~min}$. The average thicknesses at thermocouple locations were 2.75 and $2.94 \mathrm{in}$. for the respective slabs and where maximum surface temperatures were observed the thicknesses were 2.75 and $2.88 \mathrm{in}$.

Time-temperature curves for slabs 2,3 , and 7 are shown in figure 4, which gives the curves of average temperatures and the one-point maximum temperature on the unexposed surfaces. 'The three slabs were of nearly the same average thickness. Also shown is the standard furnace curve and the curve ( $\mathrm{F}$ ) of the average fumace temperatures for each test. The fire exposures for these three slabs were approximately 100 percent of the standard. The fire exposure is measured by the ratio of the area under the curve of furnace temperature to that under the standard leference curve and both above the base temperature of $68^{\circ} \mathrm{F}\left(20^{\circ} \mathrm{C}\right)$ expressed as percent.

\subsection{Partitions}

The partition tests were performed in two groups. The first group included partitions $12 t$ and 125 , the second, inade several months later after the tests of the slabs had indicated the effectiveness of the sawdust admixture in the aggregate, included 138 having only sand as the aggregate and 139 in which the aggregate was a. mixture of sand and sawdust.

The principal characteristies of the partitions of both groups and a summary of the results of the tests are given in table 2 .

TABLE 2. Partitions made with gunite concrete

\begin{tabular}{|c|c|c|c|c|c|c|c|c|}
\hline \multirow{3}{*}{$\begin{array}{c}\text { Parti- } \\
\text { tion }\end{array}$} & \multicolumn{3}{|c|}{$\begin{array}{l}\text { Composition, } \\
\text { parts by volume }\end{array}$} & \multirow{3}{*}{$\begin{array}{l}\text { A ver- } \\
\text { age } \\
\text { thiek- } \\
\text { ness }\end{array}$} & \multicolumn{4}{|c|}{ Test data } \\
\hline & \multirow{2}{*}{$\begin{array}{l}\text { Ce- } \\
\text { ment }\end{array}$} & \multirow{2}{*}{$\begin{array}{l}\text { Saw- } \\
\text { dust }\end{array}$} & \multirow{2}{*}{ Sand } & & \multirow{2}{*}{$\begin{array}{c}\text { Kind of } \\
\text { test }\end{array}$} & \multirow{2}{*}{$\begin{array}{l}\text { Expo- } \\
\text { sure }\end{array}$} & \multicolumn{2}{|r|}{ Failure } \\
\hline & & & & & & & Time & Find \\
\hline & & & & $i n$. & & $\begin{array}{l}\text { Per- } \\
\text { cent }\end{array}$ & $\min$ & \\
\hline 124 & 1 & 0 & ${ }^{a} 4$ & 2.5 & $\begin{array}{l}\text { Fire en- } \\
\text { durance. }\end{array}$ & 97 & 36 & $\begin{array}{l}\text { through. } \\
\text { Temp } 2 \mathrm{rg}^{2} \text {. }\end{array}$ \\
\hline 125 & 1 & B 0 & $t$ & 2,5 & do & 96 & 16 & $\begin{array}{l}\text { Hole } \\
\text { through. }\end{array}$ \\
\hline 138 & 1 & 0 & 4 & 2.5 & do & 86 & $\begin{array}{l}26 \\
26\end{array}$ & $\begin{array}{l}\text { Do. } \\
\text { Glow in cot- }\end{array}$ \\
\hline 139 & 1 & ${ }^{\circ} 2$ & 2 & 2.75 & $\left\{\begin{array}{l}\multicolumn{1}{c}{\text { Fo }} \\
\text { Fire and } \\
\text { hose } \\
\text { stream. }\end{array}\right.$ & $\begin{array}{r}100 \\
-\end{array}$ & $\left\{\begin{array}{l}70 \\
80\end{array}\right.$ & $\begin{array}{l}\text { Temp max. } \\
\text { Temp avg. } \\
\text { Nofailure in } \\
\text { hosestream } \\
\text { test. }\end{array}$ \\
\hline
\end{tabular}

a Beeause of different degrees of dampness of sand used in the gunite mixes, the proportions of cement to sand by weight were, respectively, $1: 4.25 ; 1: 3.4$; $1: 3.1$; and $1: 1.53$.

$b$ Six pounds of asbestos fiber per bag of cement was added to mix.

$c$ The 2 volumes of sawdust wcighed 22 pereent of the weight of 1 volume of cement.

$d$ The thickness of the partition where the maximum rise of surface temperature was observed was $2.5 \mathrm{in}$.

eThe hose stream was applied to the heated surface at the end of $82 \mathrm{~min}$ of fire exposure. 


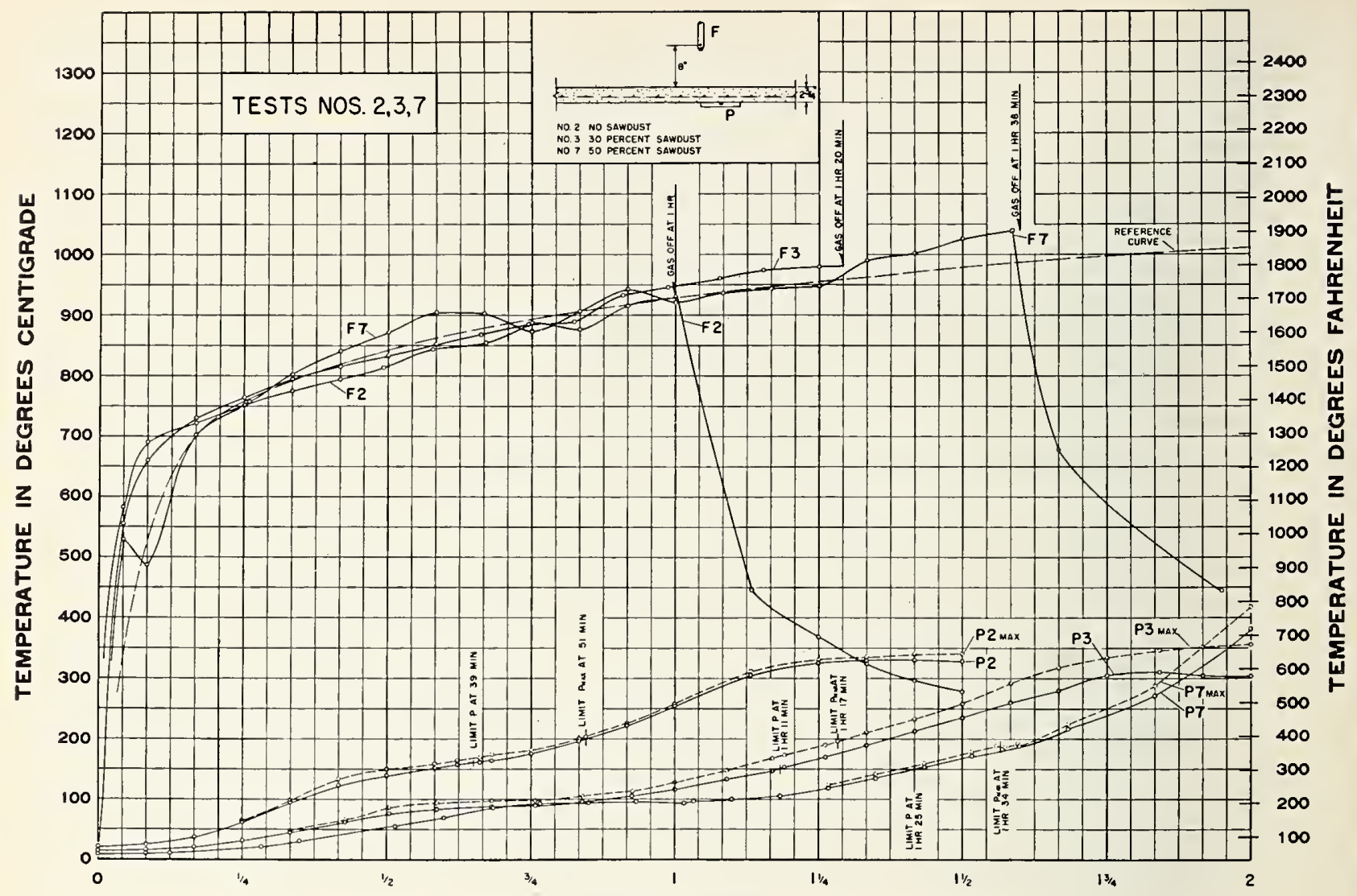

TIME IN HOURS

Figure 4. Time-temperature curves for slabs 2, 3, and $\tau$.

Partition 124 was made with a mix consisting of 1 part of portland cement to 4.25 parts of dry sand by weight, or $1: 4$ by volume.

Spalling of the fire-exposed surface accompanied by explosive reports began within $6 \mathrm{~min}$ after the start of the test and continued at frequent intervals to the end. By $11 \mathrm{~min}$, about half of the fire-exposed area had spalled, some places reaching depths of $1 \mathrm{in}$. The panel failed by the explosive formation of a hole blowing through at $26 \mathrm{~min}$. The limiting average rise of temperature on the unspalled remaining portions of the partition did not occur until $36 \mathrm{~min}$. At this time the partition had a very large center deflection. The fire was continued to $1 \mathrm{hr}$. Practically all of the fire-exposed surface had spalled off during the test. Steam began issuing from cracks at $15 \mathrm{~min}$ after the start of the test and continued throughout the test. At the conclusion, much of the reinforcing fabric in the lower third of the partition was exposed. Figure 2 shows the condition of the partition after 1 -hr fire exposure of the opposite side.

Partition 125 had 1 part of portland cement to 4 parts of damp sand by volume or to 3.4 parts of dry sand by weight. Six pounds of asbestos fiber for each bag of cement was added to the mix.

Prior to starting the test, shrinkage of the gunite had opened a $1 / 32^{-i n}$. space between the partition and test frame at the ends and top. However, there were no visible cracks in the fire-exposud face until explosive spalling commenced at about 10 min after the start of the test. At $16 \mathrm{~min}$, an explosion tore a hole about $4 \mathrm{ft}^{2}$ in area through the partition. This constituted failure. The fire was continued, however, for $20 \mathrm{~min}$ after start of the test. A considerable volume of steam issued from numerous cracks formed in the partition in the latter part of the test. The condition of the badly spalled fire-exposed side of this partition can be seen in figure 5 .

Time-temperature curves for partitions 124 and 125 are shown in figure 6 . In addition to the temperatures on the unexposed surface, curves 1 and 1 max show those for thermocouples at the reinforcing wire in the midplane of a partition. The temperature rise at this location is given as information but is not to be interpreted as affecting the criterion of failure. 


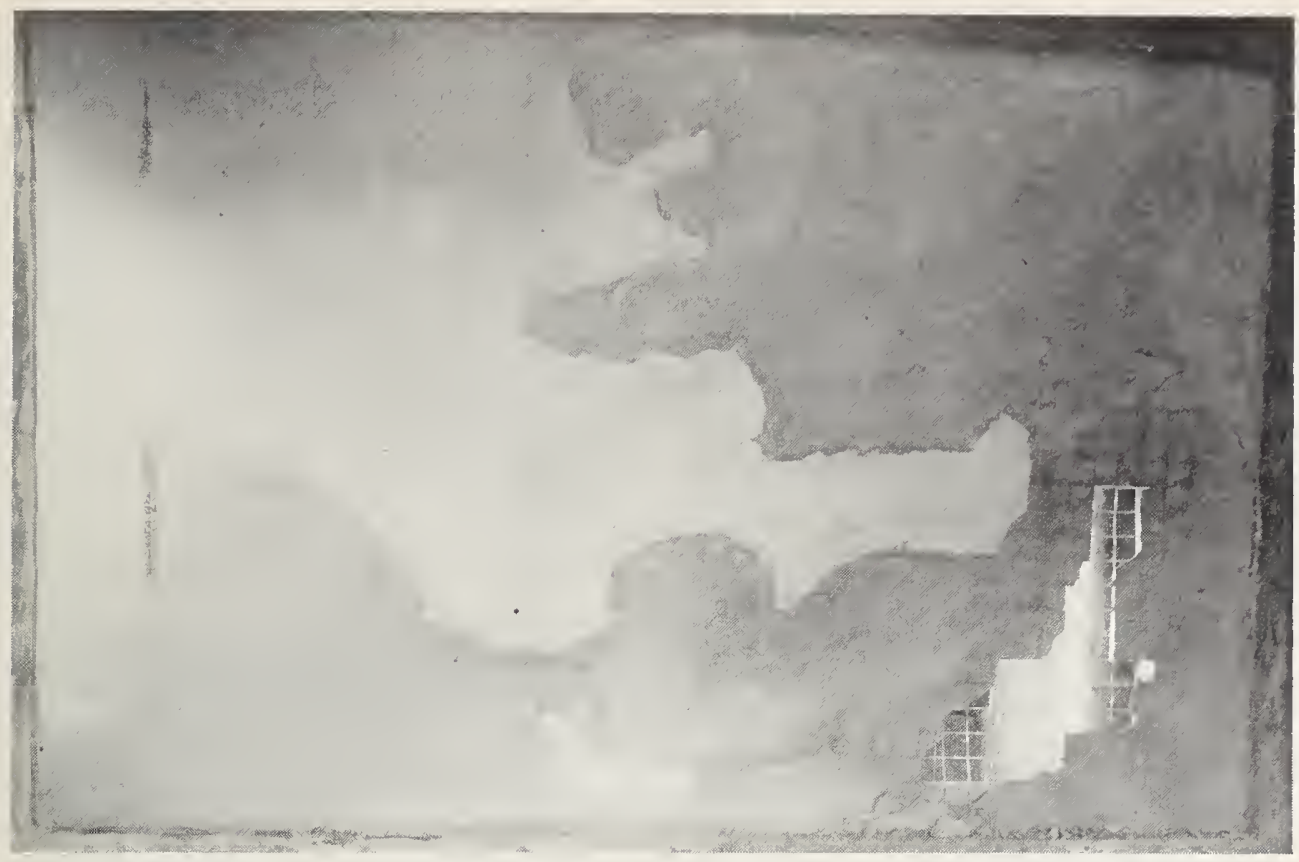

Figure 5. Fire-exposed side after 20-min fire test of partition 125.

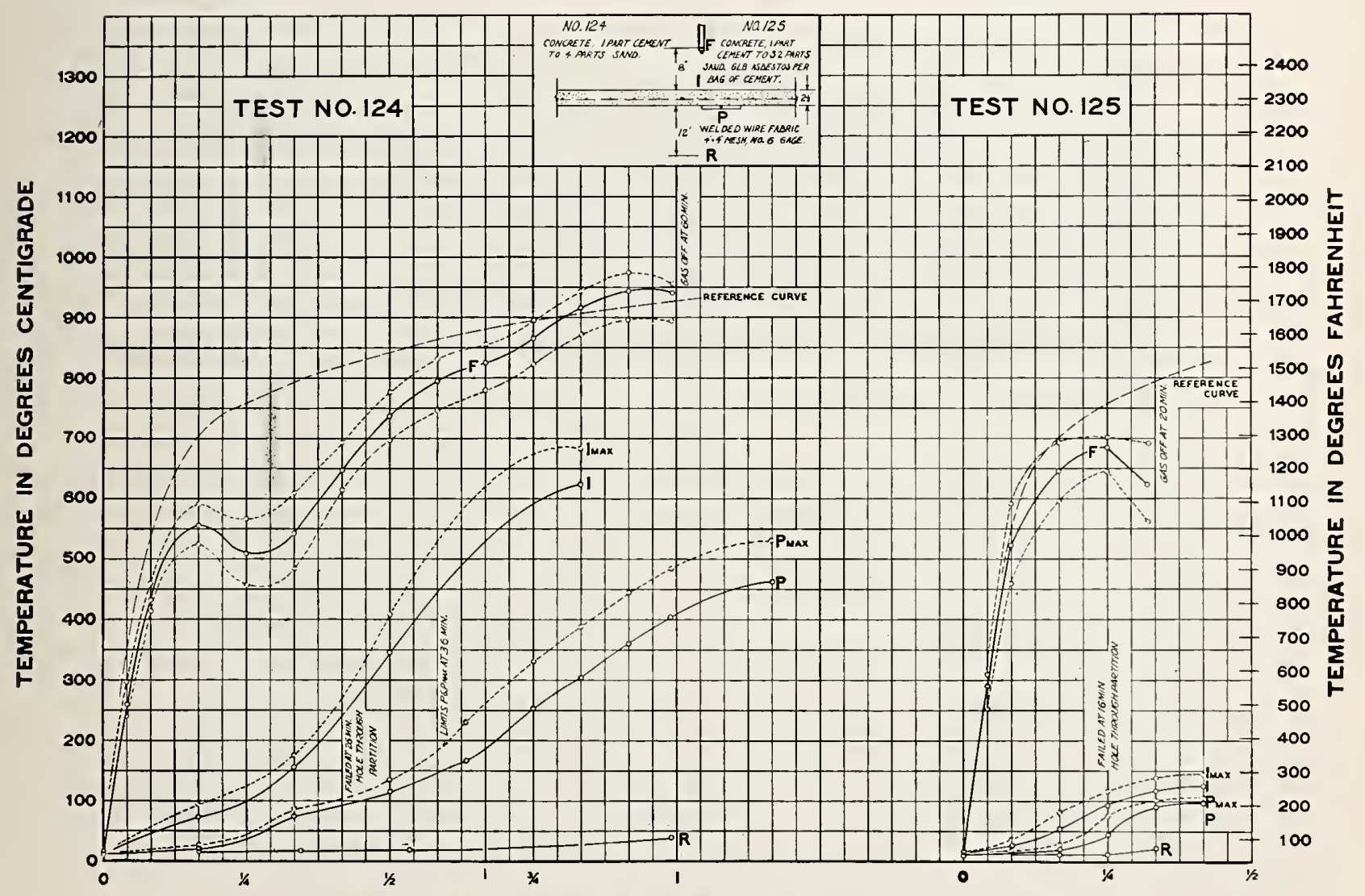

Figure 6. Time-temperature curves for partitions 124 and 125. 
Partition 138 consisted of 1 part of portland cement to 4 parts by volume of wet sand or 3.1 parts of dry sand by weight. This partition differed from 124 in its richer mix and longer drying time. At $6 \mathrm{~min}$, steam issued from several cracks. I minute later explosive popping began, and after $18 \mathrm{~min}$ considerable areas of the fireexposed surface had spalled. The panel failed at 26 min by the transmission of sufficient heat to cause glow in waste on the unexposed surface. Also, at this time, a hole $1 / 4$ by $21 / 2 \mathrm{in}$. was opened at the edge of a previously spalled area. The limiting maximum temperature rise at one point occurred at $28 \mathrm{~min}$, the limiting average rise in 36 min. The test fire was continued to $40 \mathrm{~min}$. Large cracks developed, but there was little addi- fine cracks began to form in the unexposed surface. At $9 \mathrm{~min}$, water droplets formed as condensate fron steam issuing from cracks. This contimued until the test had progressed for almost $1 \mathrm{hr}$, when the wet spots disappeared and the steam was succeeded by small quantities of smoke. At $1 \mathrm{hr} 12 \mathrm{~min}$, there were no surface cracks over $1 / 16$ in. wide. Three minutes later, the first mild-to-moderate popping sounds occurred. These were not of sufficient inteusity to suggest explosive disruption of the partition. The fire exposure was continued to $1 \mathrm{hr} 22 \mathrm{~min}$, although the end point of fire endurance had occurred at 70 min, when the limiting rise of temperature at one point on the unexposed side was attained. The limiting average rise occurred at $80 \mathrm{~min}$.

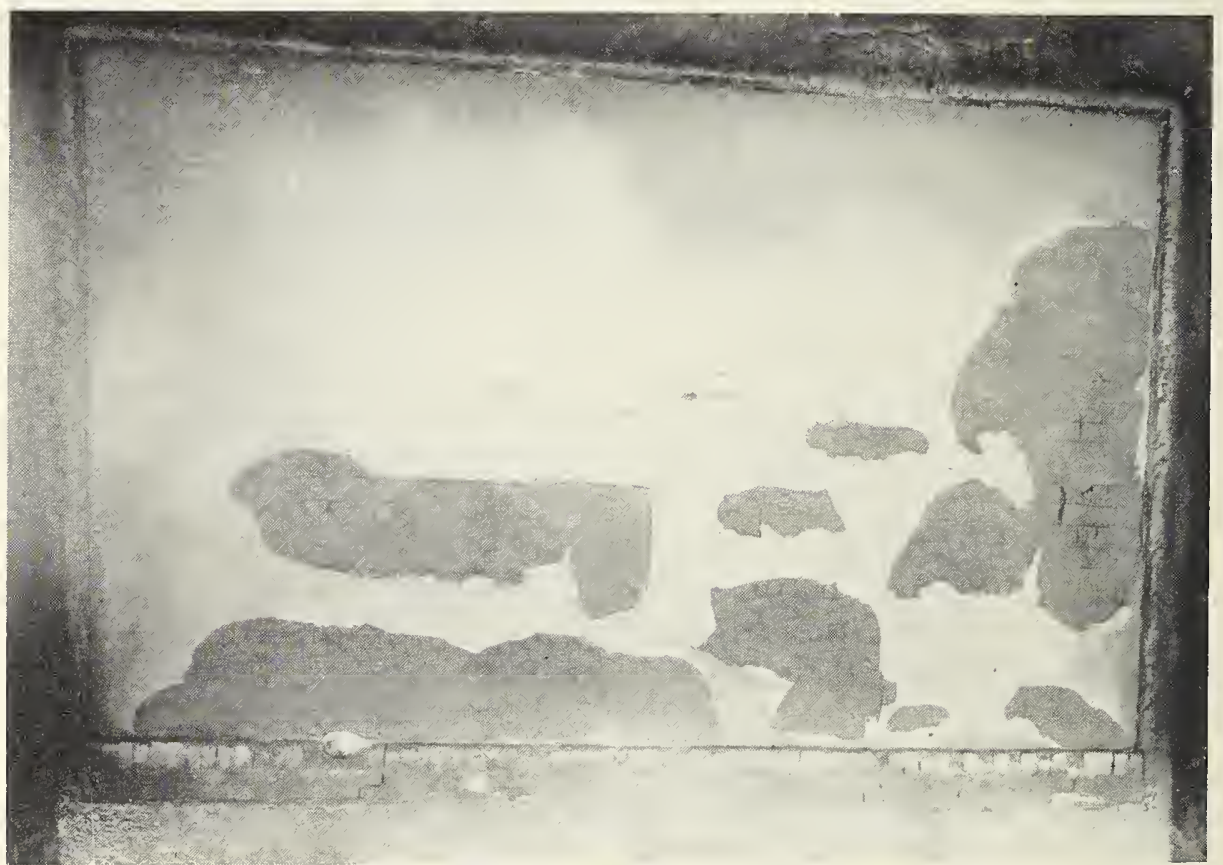

FIGuRe 7. Exposed side of partition 138 after 40-min fire test.

tional steaming. The deflection of the partition away from the fire amounted to $61 / 2 \mathrm{in}$. at the time of failure and to almost $8 \mathrm{in}$. at the conclusion of the fire exposure. The condition of the fire-exposed side of this partition after the test is shown in figure 7 .

The mix for partition 139 was also $1: 4$ by volume of cement to aggregate or 4.5 parts of cement, one part of sawdust, and 6.9 parts of sand by weight of dry materials. The aggregate consisted of equal volumes of sand and sawdust.

Before the test, it was noticed that there were several sag cracks up to $1 / 8 \mathrm{in}$. wide in the exposed face of the partition. A number of fine cracks followed the horizontal and vertical reinforcing wires. Three minutes after the start of the test,
It the conchusion of the fire-endurance test, the panel successfully withstood the application of a $11 / 8$-in.-diameter hose stream at $30-1 \mathrm{~b} / \mathrm{in} .^{2}$ pressure. The water was applied for $2 \mathrm{~min} 2 t \mathrm{sec}$ to the side that had been exposed to the fire. There was no passage of water through the gunite concrete, the unexposed face remaining dry. This partition met the requirements for a 1-hr fireresistance rating.

The condition of the exposed side of the partition immediately after the fire-endurance test can be seen in figure 8 . Figure 9 shows the same surface of the partition after the application of the hose stream. The impact of the cold water had little erosive effect. 


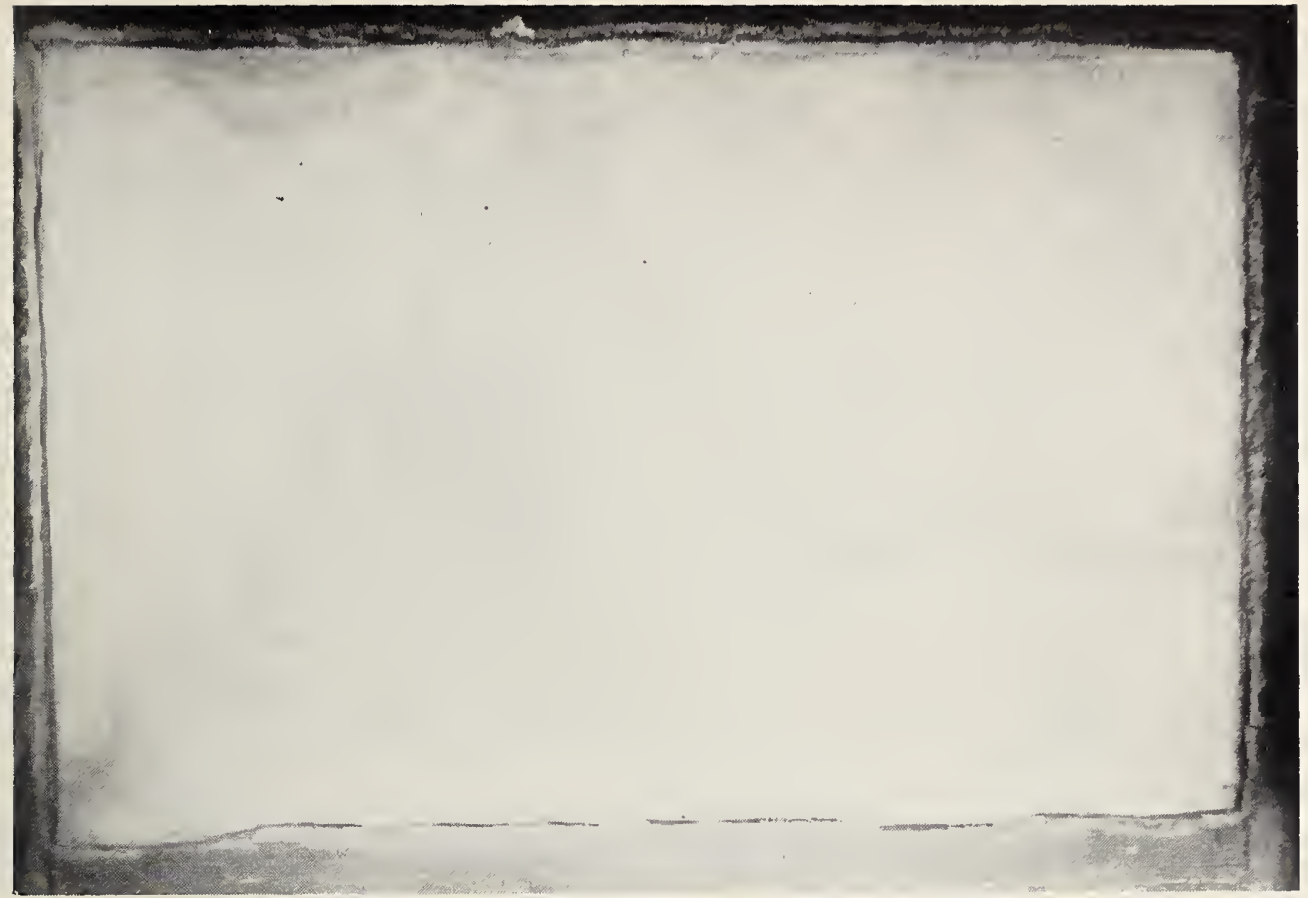

FIGURE 8. Exposed side of partition 139 after 1-hr 22-min fire test.

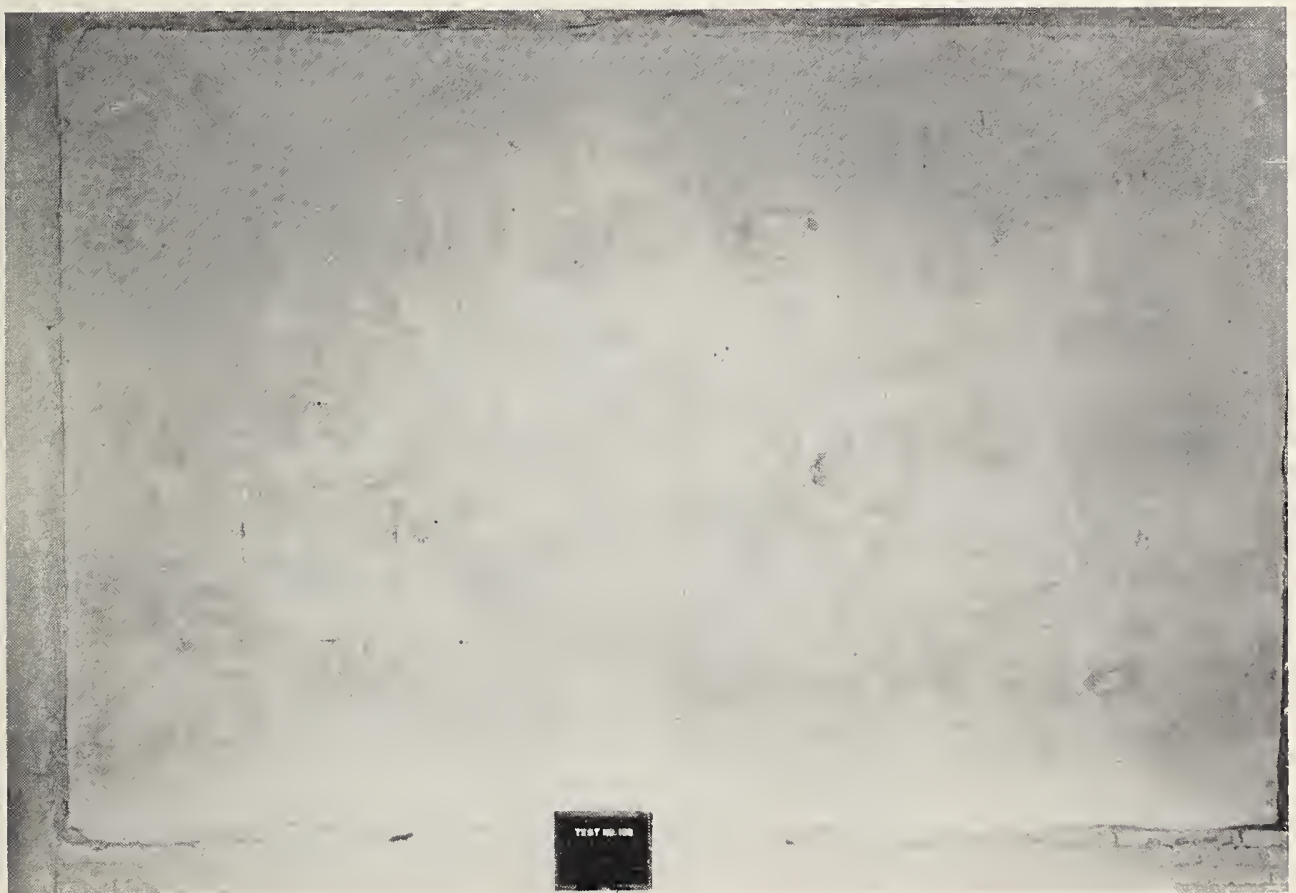

Figure 9. Partition 139 after 2-min 24-sec application of hose stream. 


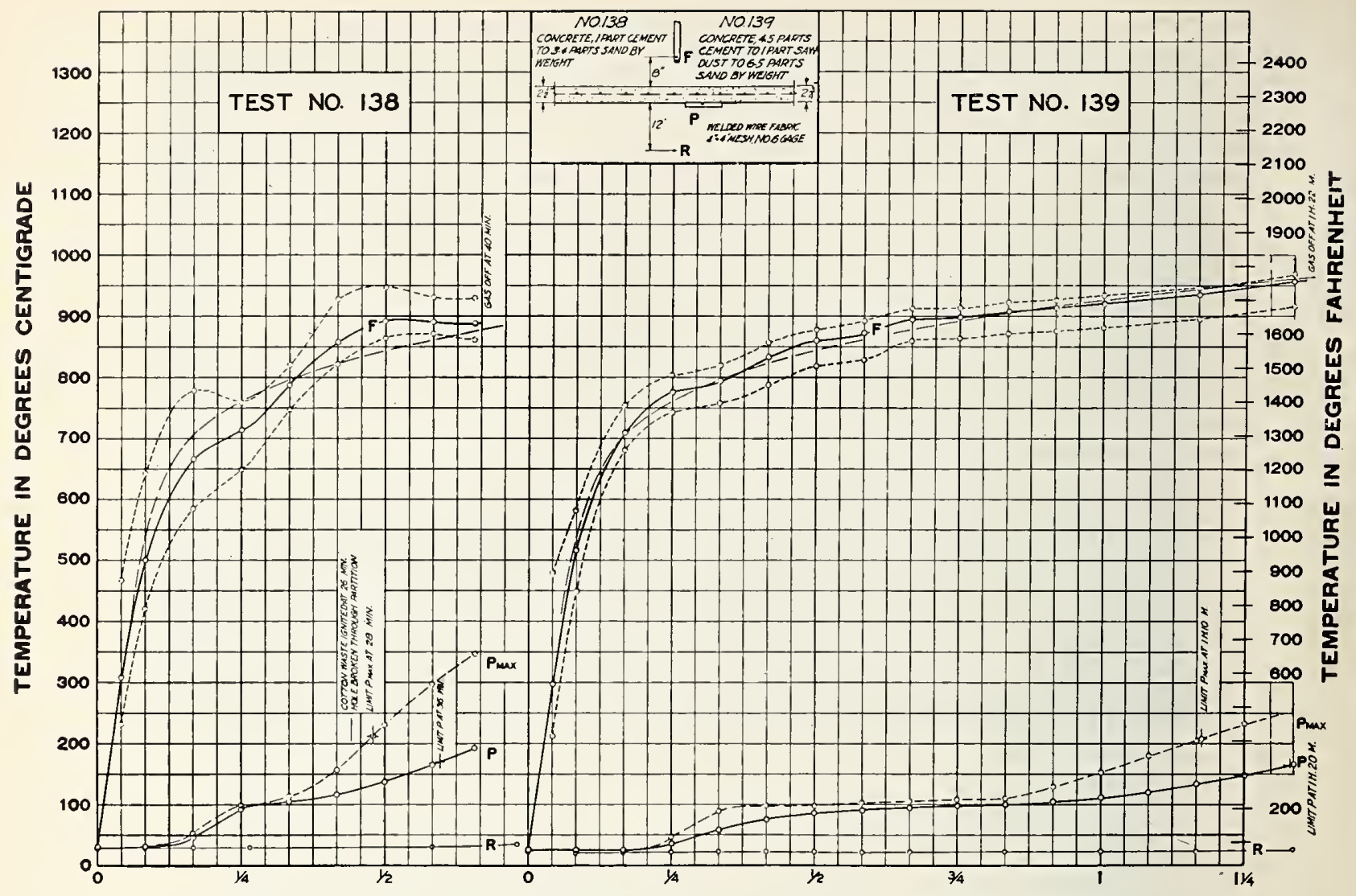

TIME IN HOURS

Figure 10. Time-temperature curves for partitions 138 and 139.

Time-temperature curves, including those for the furnace and the umexposed surfaces of partitions 138 and 139, are shown in figure 10 .

\section{Summary and Discussion}

In each of the tests of slabs, failure occurred through average rise of temperature on the unexposed surface before the limiting rise of temperature at one point was reached. 'The slabs with no sawdust failed by $250 \mathrm{deg} \mathrm{F}$ rise in 38 and $39 \mathrm{~min}$. The substitution of an equal volume of sawdust for 30 percent of the sand increased the fire-endurance limits to 66 and 71 min. By substituting sawdust for 40 percent of the sand, limits of 70 and $88 \mathrm{~min}$ were attained. With the largest quantity of sawdust used in the tests of slabs ( 50 percent by volume of the aggregate) limiting average temperature rises were reached at 85 and $103 \mathrm{~min}$. The time required to reach the limiting maximum temperature rise at one point ranged from $51 \mathrm{~min}$ for a slab with no sawdust to $107 \mathrm{~min}$ for a slab having 50 percent of the sand replaced by sawdust. The increase of fire resistance of 2.75-in.-thick

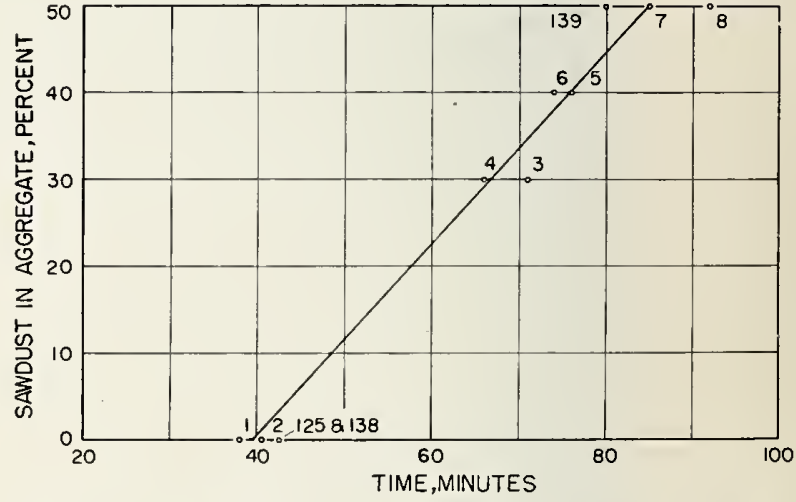

FIGURE 11. Effect of eomposition of aggregates on the fire resistance of $2.75-i n .-t h i c k$ gunite slabs and partitions.

gunite slabs resulting from increasing percentages of sawdust in the aggregate is shown in figure 11 . The values for tests of partitions 125 and 138 are those from the rise of surface temperatures in areas where previous spalling of the fire-exposed surface had not occurred. The values derived 


\section{Errat;a Sheet}

Building Materials and Structures Report 131 Fire Tests of Gunite Slabs and Partitions

The Formula on page 1J should read:

$$
T=7.3(1+2 \cdot 3 p) t^{\frac{5}{3}}
$$




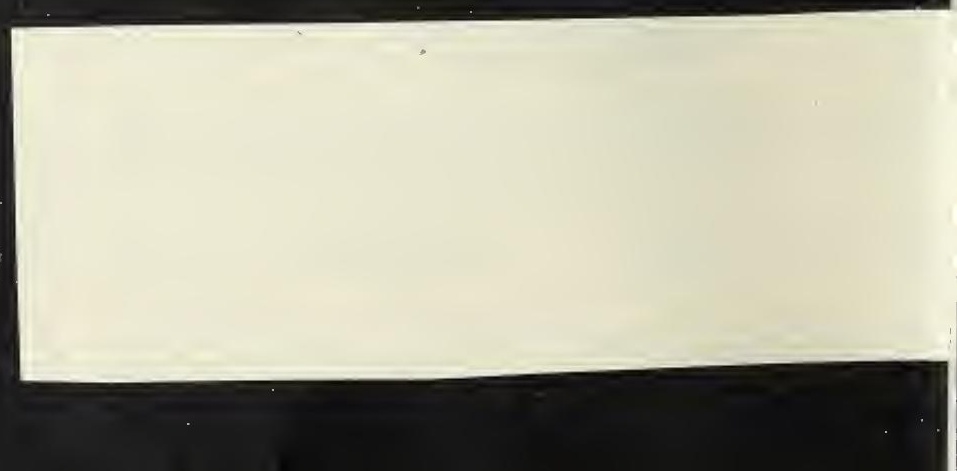


from tests have been projected to the 2.75 -in. thickness on the basis of the fire resistance, varying as the $5 / 3$ power of the thickness of the slab.

The partitions without sawdust failed early in the fire tests by the formation of holes through them. This occurred in 26,16 , and $26 \mathrm{~min}$ for partitions 124,125 , and 138 , respectively. In addition, partition 138 failed by transmission of heat sufficient to cause glow in waste on the unexposed side at the same time that $a$ hole was formed elsewhere on the partition. Addition of asbestos fiber to the mix, as for partition 125, did not enhance the fire resistance; rather, this partition failed in less time than did any of the others. However, when the aggregate consisted of half sand and half sawdust, as in partition 139 , a fire-endurance limit of $70 \mathrm{~min}$, determined by the rise of maximum temperature at one point, was achieved. The limiting average rise of temperature was reached at $80 \mathrm{~min}$. Not only were the fire-endurance limits greater for this partition, but there were none of the disluptive explosive effects which characterized the tests of the other three partitions.

An empirical formula suitable for estimating the time required to raise the surface temperature of gunite slabs or partitions $250 \mathrm{deg} \mathbf{F}$, provided that spalling is avoided, has been developed from the derived data and from data obtained in previous tests with partitions of other aggregates having a greater range of thickness. ${ }^{4}$ This formula is applicable to gunite composed of 1 part of portland cement to 4 parts of aggregate composed of silica sand and sawdust. The amount of sawdust is limited to not more than one-half of the total of aggregate. The formula is

$$
T=7.3(1+2.3 p) t \frac{5}{3}(1+2.3 p) t \frac{5}{3},
$$

where

$T=$ the time in minutes to reach the average rise of $250 \mathrm{deg} \mathrm{F}$ under asbestos pads on the unexposed surface.

$t=$ the thickness in inches of the wall or slab in the range 2 to $3 \mathrm{in}$.

$p=$ the proportion of sawdust by volume in the aggregate in the range 0 to 0.5 .

Gunite, as usually made with concrete sand aggregate, was found to be generally unsatisfactory for fire-resistive constructions. The spalling that

4 See BMSr1, D. 32, Tests Nos. X 1 and X 2. caused the early failure in the partitions was accompanied by explosive violence endangering those in the nearby area. Failure of the gunite by spalling was attributed to expansion stresses and the water retained in the dense material. Unable to escape and with little space for expansion, the water became heated during the fire test and increased in pressure until it attained a force sufficient to disrupt the thermally strained concrete. Absence of violent spalling in the two slabs made without sawdust was considered to be the result of a somewhat lower density concrete $\left(134 \mathrm{lb} / \mathrm{ft}^{3}\right)$ and a more thorough drying than had been accorded the partitions. To eliminate the possible presence of excessive free water, the drying time of one partition having only sand aggregate was greatly increased over those previously tested, however, little diminution of spalling was apparent in the fire test. Perhaps the dense structure of gunite concrete prevented the escape of water within a reasonable drying period.

The use of wood sawdust as part of the aggregate of the gumite increased the time to failure by temperature rise on the unexposed side and obviated explosive effects. The sawdust, by increasing the porosity of the concrete, allowed the occluded water, together with the distillation products of the wood, to escape as vapor. As the greater temperature rise occurred on the fire-exposed side of the test structure, the vapors tended to issue first on that side. Thus the sawdust serves to provide chamnels for the escape of the water retained in the concrete and prevent spalling. It also slows the rise of temperature on the unexposed side by the early transfer of heat-absorbing vapor to the fire side of the test structure.

As is true for other lightweight aggregates, the use of sawdust reduces the strength of the concrete. However, the current and proposed uses of gunite as a fire-protective covering or in curtain-wall constructions are such that great strength is often of minor importance. Chemically treated or inert sawdust should have little deleterious effect on the portland cement of the mix.

The improvements achieved by increased proportions of sawdust to sand in the concrete mixes described in this report suggests that the optimum proportions for fire protection had not been reached.

Wasmington, September 13, 1951. 





\section{BUILDING MATERIALS AND STRUCTURES REPORTS}

\section{[Continued from cover page II]}

BMS34

BMS36

BMS38

BMS39

BMS42

BMS43

BMS44

BMS47

BMS48

BMS49

BMS50

BMS51

BMS52

BMS53

BMS54

BMS55

BMS58

BMS59

BMS60

BMS61

BMS62

BMS63

BMS64

BMS65

BMS66

BMS67

BMS68

BMS69

BMS70

BMS71

BMS72

BMS73

BMS74

BMS75

BMS76

BMS77

BMS78

BMS79

BMS80

BMS81

BMS82

BMS83

BMS84

BMS85

BMS86

BMS87

BMS89

BMS90
Performance Test of Floor Coverings for Use in Low-Cost Housing: Part 1

Structural Properties of Wood-Frame Wall, Partition, Floor, and Roof Constructions With "Red Stripe" Lath Sponsored by The Weston Paper and Manufacturing Co

W. E. Dunn Manufacturing Co
Structural Properties of a Wall Construction of "Pfeifer Units" Sponsored by the $10 \phi$ Wisconsin Units Co

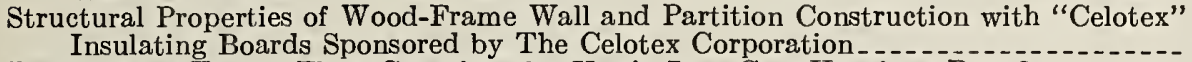
Insulating Boards Sponsored by The Celotex Corporation Performance Test of Floor Coverings for Use in Low-Cost Housing: Part 2_._. Surface Treatment of Steel Prior to Painting

Structural Properties of Prefabricated Wood-Frame Constructions for Walls, Partitions, and Floors Sponsored by American Houses, Inc

Structural Properties of "Precision-Built" Frame Wall and Partition Constructions Sponsored by the Homasote Co

Metallic Roofing for Low-Cost House Construction

Stability of Fiber Building Boards as Determined by Accelerated Aging

Structural Properties of "Tilecrete Type A" Floor Construction Sponsored by the Tilecrete Co

Effect of Ceiling Insulation Upon Summer Comfort

Structural Properties of a Masonry Wall Construction of "Munlock Dry Wall Brick" Sponsored by the Munlock Engineering Co

Effect of Soot on the Rating of an Oil-Fired Heating Boiler

Effects of Wetting and Drying on the Permeability of Masonry Walls

Strength of Soft-Soldered Joints in Copper Tubing o

Properties of Adhesives for Floor Coverings Bricks Produced in the United States

Structural Properties of Two Nonreinforced Monolithic Concrete Wall Constructions.- 10

Structural Properties of a Precast Joist Concrete Floor Construction Sponsored by the Portland Cement Association

Moisture Condensation in Building Walls

Solar Heating of Various Surfaces.

Methods of Estimating Loads in Plumbing Systems

Plumbing Manual.Walls, Partitions, Floors, and Roofs, Sponsored by Herman A. Mugler.........

Performance Test for Floor Coverings for Use in Low-Cost Housing: Part 3...

Stability of Fiber Sheathing Boards as Determined by Accelerated Aging-_-_-_-_.-

Asphalt-Prepared Roll Roofings and Shingles

Fire Tests of Wood- and Metal-Framed Partitions
Structural Properties of "Precision-Built, Jr." Prefabricated Wood-Frame Wall Construction Sponsored by the Homasote Co Profabe

Indentation Characteristics of Floor Coverings Steel Constructions for Walls, Partitions, and Roofs Sponsored by the Tennessee Coal, Iron \& Railroad Co

Survey of Roofing Materials in the North Central States
Effect, of Outdoor Exposure on the Water Permeability of Masonry Walls -10

Properties and Performance of Fiber Tile Boards

Structural, Heat-Transfer, and Water-Permeability Properties of Five Earth-Wall Constructions

Water-Distributing Systems for Buildings .

Performance Test of Floor Coverings for Use in Low-Cost Housing: Part 4

Field Inspectors' Check List for Building Constructions (cloth cover, 5 x 736 inches) --.-

Water Permeability of Walls Built of Masonry Units

Strength of Sleeve Joints in Copper Tubing Made With Various Lead-Base Solders...

Survey of Rooflng Materials in the South Central States.

Dimensional Changes of Floor Coverings With Changes in Relative Humidity and Temperature Construction Sponsored by the General Shale Products Corporation.

A Method for Developing Specifications for Building Construction-Report of Subcommittee on Specifications of the Central Housing Committee on Research, Design, and Construction

Wood-Frame Wall Construction Sponsored by the Homasote Co-_tions for Walls,
Structural Properties of "PHC" Prefabricated Wood-Frame Construction Floors, and Roofs Sponsored by the PHC Housing Corporation.......... 15\& 


\title{
BUILDING MATERIALS AND STRUCTURES REPORTS
}

\author{
[Continued from cover page 111]
}

BMS92

BMS93

BMS94

BMS95

BMS96

BMS97

BMS98

BMS99

BMS100

BMS101

BMS102

BMS103

BMS104

BMS105

BMS106

BMS108

BMS109

BMS110

BMS111

BMS112

BMS113

BMS114

BMS115

BMS116

BMS117

BMS118

BMS119

BMS120

BMS121

BMS122

BMS123

BMS124

BMS125

BMS126

BMS127

BMS128

BMS129

BMS130

BMS131
Fire-Resistance Classifications of Building Constructions - - Accumulation of Moisture in Walls of Frame Construction During Winter Exposure - $10 \$$ Water Permeability and Weathering Resistance of Stucco-Faced, Gunite-Faced, and

"Knap Concrete-Unit" Walls .

Tests of Cement-Water Paints and Other Waterproofings for Unit-Masonry Walls

Properties of a Porous Concrete of Cement and Uniform-Sized Gravel_.... Experimental Dry-Wall Construction With Fiber Insulating Board. Physical Properties of Terrazzo Aggregates Structural and Heat-Transfer Properties of "Multiple Box-Girder Plywood Panels" for Walls, Floors, and Roofs . _ _ Relative Slipperiness of Floor and Deck Surfaces Strength and Resistance to Corrosion of Ties for Cavity Walls Painting Steel

Measuremeen of Ueat J

Measurements of Heat Losses From Slab Floors Structural Properties of Prefabricated Plywood Lightweight Constructions for Walls, Partitions, Floors, and Roofs, Sponsored by the Douglas Fir Plywood Association Paint Manual With Particular Reference to Federal Specifications _._._. Laboratory Observations of Condensation in Wall Specimens Temperature Distribution in a Test Bungalow With Various Heating Devices..... $10 d$ Strength of Houses: Application of Engineering Principles to Structural Design Paints for Exterior Masonry Walls Performance of a Coal-Fired Boiler Converted to Oil Properties of Some Lightweight-Aggregate Concretes With and Without an ÄirEntraining Admixture

Fire Resistance of Structural Clay Tile Partitions Temperature in a Test Bungalow With Some Radiant and Jacketed Space Heaters.-- $25 \phi$ A Study of a Baseboard Convector Heating System in a Test Bungalow Preparation and Revision of Building Codes Fire Resistance of Walls of Lightweight Aggregate Concrete Masonry Units. Stack Venting of Plumbing Fixtures. Wet Venting of Plumbing Fixtures Fire Resistance of Walls of Gravel-Aggregate Concrete Masonry Units. Investigation of Failures of White-Coat Plasters_... Physical Properties of Some Samples of Asbestos-Cement Siding Fire-Tests of Wood-Framed Walls and Partitions With Asbestos-Cement Facings Fire Tests of Steel Columns Protected With Siliceous Aggregate Concrete.......-. $15 \phi$ Stone Exposure Test Wall The Self-Siphonage of Fixture Traps Effect of Aging on the Soundness of Regularly Hydrated Dolomitic Lime Putties.-..- $15 \phi$ Atmospheric Exposure Tests of Nailed Sheet Metal Building Materials_._-_-_-_-_ 20 Fire Endurance of Shutters for Moving-Stairway Openings _ _._. Methods and Equipment for Testing Printed-Enamel Felt-Base Floor Covering Fire Tests of Gunite Slabs and Partitions_. . . . . . . . . 